\title{
Organized Smuggling of Goods in the Criminal Law of Iran and Turkey
}

\author{
Alireza Aghazadeh ${ }^{1}$, Mohammadali Ardebili ${ }^{1}$, Mohammad Ashouri ${ }^{1} \&$ Mohammadali Mahdavisabet $^{1}$ \\ ${ }^{1}$ Department of Criminal Law and Criminology, Faculty of Law and Politics, Science and Research Branch, \\ Islamic Azad University, Tehran, Iran \\ Correspondence: Mohammadali Ardebili, Department of Criminal Law and Criminology, Faculty of Law and \\ Politics, Science and Research Branch, Islamic Azad University, Tehran, Iran. E-mail: isisarvak@gmail.com
}

Received: July 7, 2016

doi:10.5539/jpl.v10n5p24
Accepted: October 15, 2016 Online Published: December 18, 2016

URL: https://doi.org/10.5539/jpl.v10n5p24

\begin{abstract}
Smuggling of goods, known as one of the most obvious instances of economic crimes, has done irreversible harms to the economic systems of countries through placing obstacles in the way of productive investment, undermining healthy competitions in business, and finally forming and expanding underground and hidden economies. Creating the areas of money laundering and committing transnationally organized crimes, smuggling jeopardizes the economic and political security of countries seriously. On the other hand, committing smuggling crimes in groups has led to the expansion and intensification of such actions and made it quite difficult for the criminal justice systems to identify and deal with them. Organized crimes, which are among more evolved forms of group crimes, influence different areas of society because such crimes are compulsorily accompanied by the prevalence of bureaucratic and financial corruption. In addition, such crimes have negative impacts on the cultures of societies. Based on the proportionality of crimes, punishments, and distributive justice and the theory of punishment, criminal policy makers, therefore, have considered the quality of committing smuggling crime, such as organization, in order to effectively deal with this phenomenon in different countries. They have also showed differentiating and strict reactions to this type of crime. The aim of the current study was to investigate the theoretical concepts and foundations of organized smuggling of goods in Iran and Turkey. It was also intended to study the legal approaches adopted by these countries to this type of crime along with the similarities and differences of their legal systems.
\end{abstract}

Keywords: organized smuggling of goods, criminal group, smuggling network, criminalization, differential reactions

\section{Introduction}

\subsection{The Concept of Organized Smuggling of Goods}

There is a long history of committing crimes in an organized way in some countries. People have sometimes thought of it as mafia. Academics, authors of legal papers, criminal judges, and journalists have been discussing it for over one century. However, the term Organized Crime is among the concepts coming from the literature of criminal sociology and criminology into criminal law. Some of the international institutions and lawyers have tried to define it. In this regard, some definitions have considered the indicators of group involvement bearing single and continuous structures with methodological organizations mainly aimed at obtaining money through highly illegal activities, gaining financial benefits, or even political power. Some authors believe that an organized crime, or corporate crime as they interpret, refers to criminal actions committed by some groups of individuals who usually get together cohesively in an organization to gain financial benefits. In other words, each individual plays a role in achieving the main goal which is to gain benefits and interests. Finally, everyone takes a share of the benefits resulting from the joint activities (Borricand, 1999).

The Palermo Convention did not define organized crimes; however, Paragraph (A) of Article 2, explained the meaning of an organized crime. According to this paragraph, an organized criminal group refers to an organized group including three or more individuals get together for a specific period of time to commit one or more crimes or severe violations in order to gain financial benefit or other material benefits directly or indirectly in a collaborative manner. 
The International Criminal Police Organization (INTERPOL) has also presented a similar definition of an organized criminal group when it says: "The term refers to every group having a cohesive structure and a primary objective of gaining money through illegal activities and acts of corruption or intimidation."

\subsection{Qualities and Conditions of Committing the Organized Smuggling of Goods}

1) Smuggling Network: This network is meant to provide goods inside the country. The goods are supposed to be smuggled out of the country (export smuggling). It is also intended to provide goods abroad to smuggle them into the country (import smuggling). Then these smuggled goods are delivered to the cross-border smuggling network.

2) Cross-Border Smuggling Network: As the name implies, this network is responsible for the affairs pertaining to importing or exporting smuggled goods. Investigating the available routes for smuggling, this networks selects one of the two ways including customs smuggling and non-customs smuggling (or both) to transfer smuggled goods.

3) Distribution Smuggling Network: This network is meant to distribute and sell the smuggled goods imported to the country (import smuggling) or distribute and sell the smuggled goods exported from the country (export smuggling).

Given the abovementioned definitions and legal characteristics, the fulfillment of the following conditions is essential for the realization of organized smuggling crime.

First, the membership of more than three individuals in a criminal group and their joint and collaborative activities in smuggling goods would not be merely enough to refer to this type of crime as organized smuggling crime but other legal conditions are necessary. However, a systematic organization needs to have a leader or a boss who should be practically responsible for coordination, guidance, leadership and the division of labor assigned to every member (Bakhshinejad, 2001). If the activities of collective groups are performed without the leadership and guidance of one particular individual or more, the case cannot be criminally prosecuted due to the lack of the main component of organized smuggling of goods. On the other hand, the case can be prosecuted in the form of participation in smuggling crime. Therefore, it can be stated that there is the absolute public-private relationship between organized smuggling crimes and participation in smuggling goods. Put it in another way, each organized crime is a form of participation in crime; however, any participation in smuggling is not considered to be an organized crime (Tavasolizadeh, 2013).

Second, one of the main conditions of the realization of organized smuggling crime is coordination, planning, solidarity, and division of labor in the group in order to achieve the predetermined goals and common interests. In the other words, the existence of a cohesive and disciplinary structure strengthens and perpetuates the group. Thus, it appears that simple thoughts, spirits, mindsets, or goals are not enough for sentencing the committers of a crime, and a strong will and actions on which some individuals have consulted and agreed on and a clear plan to commit the crime or start committing the crime are necessary to vote that a criminal group is formed. In other words, the manifestation of several wills, consulting and studying the provisions of a crime, is essential. Moreover, based on planning and dividing labors, the members of group would consider coordination and common purpose in order to take actions in the smuggling of goods and share the benefits resulting from criminal activities with respect to a prior agreement (Günay, 2007). Therefore, minor, indirect, and marginal factors existing in smuggling chain do not deserve punishment. For instance carrying tools such as chain by whom were hired and sharing an amount of money with the group without knowing the intention of the group is not considered as crimeIn fact, such individuals are merely hired to transfer goods from one place to another or to keep them at a particular place for a certain period of time. Thus, it can be stated that the distinction between crimes committed by the individuals outside a group and the activities done by the members of an organized group is that in the latter, they share the purpose and benefits but not in the second.

Third, the legislator has codified a special dedicated criminal justice system in the criminalization and punishment of organized crimes regardless of the regularity of principles and general presumptions of criminal law. In fact, if the procedural and substantive conditions pertaining to the number of members are fulfilled, the purposes and common goals are unified, and members make plans in coordination led by one particular individual or more, each member of the group having knowledge of the purposes takes actions, regarding the plans made by the group, in the process of the material element of crime (including preliminary or executive) or provides the conditions for smuggling crime (including guidance, leadership, planning, instructing the ways of committing crimes, faking documents, making provisions, and so on) will be considered as an accomplice in the main crime of smuggling (Seif, 1999). Then the accomplice or accomplices deserve punishment like other members of the group (although the behaviors of some members are considered as complicity in smuggling by 
the legislator. In fact, the legislator considered all the operations performed by the members of the group to commit organized smuggling as crime.The legislator actually did not pay attention to the role, impact, and involvement of each member and the quality of the actions taken by them and found all the members of a group committers of the organized smuggling crime (Sadeghi, 1997). A severer punishment has been considered for the leader, and equal penalties have been set for each member because in an organized crime, or corporate crime, each member would play a role in achieving the main goal in order to finally own a share of benefits due to the joint collective activity. Therefore, the role and task of each member may alternatively change in different steps of the crime i.e. one individual may be an assistant in one step, whereas the same individual may be a criminal in another step.

\section{Organized Smuggling of Goods from the Perspective of Laws in Iran and Turkey}

According to Article 130 of the Islamic Penal Code passed in 2013, the leadership of criminal groups was considered one of the factors intensifying the punishment. The First Note of this article defines the criminal group as follows: a criminal group refers to a relatively cohesive group comprised of three or more individuals gathered to commit crimes. The purpose of the group to commit crimes may be derailed after the formation of the group. Moreover, the Second Note of this article defines the leadership of a criminal act as forming, designing, organizing, or running a criminal group (Asadi, 2007).

Although the term organized was not mentioned in the First Note Article 130 of the Islamic Penal Code (passed in 2013), the inclusion of defining an organized group is deducted from the title of the Forth Chapter (Leadership of an Organized Criminal Group).

In a new and commendable action, the law against smuggling presented a clear and comprehensive definition of organized smuggling. In Paragraph (C) of the First Article of this law, organized smuggling is defined as follows: it is a crime committed by a relatively cohesive group comprised of three or more individuals making plans, group guidance, and division of labor for smuggling or for the purpose of group to commit the smuggling crime and may be diverted after formation of the group (Javanmard, 2013).

In consistence with the policy of criminalization and differential punishment for organized smuggling crimes, the Iranian legislator considered this crime to be among the causes of intensifying punishment. In addition, Articles 29 and 29 of manifesto law set more intense for the members of organized smuggling groups, and the notes of these two articles comply with the proportionality of punishment with the responsibility and role of each member (stated in Article 130 of IPC) for those who have organized, guided, or led roles in this type of crime. Regarding cases, the utmost punishments were predicted in these articles. It is worth mentioning that the legislator has also adopted such an approach in other similar cases due to the importance and devastating effects of some crimes. However, in Paragraph (A) of Article 2 against human trafficking (passed in 2004), the legislator considered the mere formation and management of a gang or group meant to commit human trafficking to be a crime. These actions, which are introductions to smuggling and may finally be a start for human trafficking, were considered complete and independent crimes by the legislator. This situation indicates the legislator's compliance with the zero tolerance policy and strictness in this field. It can actually be justified with a legislative approach based on encountering the committers of such crimes (prevention crimes) severely and shutting the gate to target crime in the first place (Bahrami and Ghasemi, 2007). In Article 499 of IPC (passed in 1996), the legislator also criminalized the absolute membership of individuals in one of the groups and communities formed to violate the security of country with the knowledge of their purposes and set three to five years of imprisonment. Eventually, the signified article can be deducted that practical activities, roles, involvements, and direct or indirect impacts of each member in the advancement of purposes of the groups violating the security of country while it would not have any effects in the realization of the abovementioned crime. Similarly, the legislator's approach to the criminalization of the collective crime and compromising with committing a crime against national security, lands, properties, and individuals, known as the subject of Articles 610 and 611 of IPC which can be referred to as the prevention crime. In these articles, the unity of some individuals and their consultation to commit one of the signified crimes is enough for voting that the crime has occurred, providing situations for committing a crime, is not the necessary condition for voting an action is crime. Therefore, since more than one individual would be involved in organized smuggling crimes with the collusion and collaboration of the members of these criminal networks, it is essential to confront the manifestations of such illegal and dangerous activities more severely because they result in more harmful effects on society.

In the Fourth Article of Turkish law against smuggling passed in 2007 and the following reforms (Albayrak, Mustafa, turk ceza kanunu, adalet yayinevi. Ankara 2010) and Article 220 of Turk Ceza Kanunu (2004), the organized crime was pointed out without providing a clear and accurate definition of this crime. In Article 220 of 
TCK, some of the qualities and characteristics pertaining to the organized crime were mentioned. For instance, one of the characteristics indicating the realization of an organized crime is the membership of a minimum number of three individuals in an organized criminal group. In the First Paragragh of Article 4 of Turkish law against smuggling (2007), the commitment of an organized smuggling crime was considered to be among the intensified qualities of crime intensifying the punishments twice as what was determined in previous articles (Albayrak, 2012).

It is worth mentioning that according to the Turkish legislator the simple participation of three or more individuals in the smuggling of goods (without having the description of an organized group) considered among the causes intensifying punishment in the Second Paragraph of Article 4 of the law against smuggling (2007). In addition to the determined punishment for each accomplice, half of the legal punishments were predicted as the intensification of punishment. However, the Iranian legislator paid attention merely to the special quality of committing crimes in an organized way and disqualified the collaboration and participation in smuggling of goods despite the importance and harmful effects. According to Article 66 of the same law, the independent criminal responsibility of each accomplice (for imprisonment and flogging) and the relative criminal responsibility of each accomplice (for the whole legal fine and the share of each accomplice) were determined. Since committing the smuggling crime collaboratively in groups along with the frequency and repetition of smuggling crimes can be a dangerous and special characteristic, the distributive theory of punishment proportionality and enhancement of the preventive aspects of punishments would require the differential criminalization of such crimes (Günay, 2009). Therefore, the legislator should consider special paragraphs pertaining to participation in the crime of smuggling goods (especially the involvement and participation of more than three individuals) to determine criminal and noncriminal actions (Aidin, 2012).

In Article 220 of TCK (2004), the formation and management of an organized criminal group formed to commit crimes and also the membership in such groups along with financial supports provided for them were criminalized. Therefore, the crime boss, manager, supplier, and financial supporters of such groups were supposed to be imprisoned between 2 and 3 years while the minor members of such groups would be put behind the bars between 1 and 3 years. The investigation of Iran's criminal laws indicated the formation of an organized group (except for the special cases of Paragraph A of Article 2 of the law against human trafficking and Articles 498 and 499 of IPC, passed in 1996, pointing out the organized formation of groups and membership in them) in order to prevent from committing a crime, has not totally been criminalized yet. In some cases, the legislator stated that the commitment of crime in an organized deserves severe punishment. Therefore, it appears that the political-legal policy of Iran criminalized merely the formation, management, and membership in organized groups to fill in the obvious gap and prevent the occurrence of such crimes by such groups (like the action taken by the Iranian legislator in Paragraph A of Article 2 of the law against human trafficking) and an appropriate punishment were determined for the creators and members of such groups (Ertuğrul, 2004).

\section{Conclusion}

There is a long history of committing crimes in an organized way in some countries. People have sometimes thought of it as mafia. The Palermo Convention did not define organized crimes; however, Paragraph A of Article 2 of this convention attempted to explain the meaning of an organized crime in the lieu of clarification. According to this paragraph, an organized criminal group refers to a group comprised of three or more individuals get together for a particular period of time in order to commit one or more crimes or severe violations, addressed in this convention, to gain direct or indirect financial benefits or other material interests in a collaborative way. In a novel and commendable action, the law against smuggling of goods presented a clear and comprehensive definition of organized smuggling. In Paragraph (C) of the First Article of this law, organized smuggling was defined as follows: it is a crime committed by a relatively cohesive group comprised of three or more individuals making plans, group guidance, and division of labor for smuggling while the purpose of group to commit the smuggling crime is diverted after formation of the group. In the Fourth Article of Turkish law against smuggling (2007) and following the reforms or that article and based on Article 220 of TCK (2004), organized crime was pointed out without any clear and accurate definition. In Article 220 of TCK, some qualities and characteristics pertaining to organized crimes were mentioned such as the membership of a minimum number of three individuals in the group. The First Paragraph of Article 4 of TCK (2007) also considered the commitment of organized smuggling crime to be among the conditions intensifying the crime and a cause of intensifying the punishment twice as what was determined in previous cases. Since there should be more than two individuals involved in the organized smuggling of goods along with collusion and collaboration of the members of criminal networks, it is essential to confront the manifestation of such illegal actions more intensely and appropriately because they have more harmful effects on society. Considering the rules stated in Article 220 
of TCK along with Paragraph A of the Second Article of the law against human trafficking and Articles 499 and 498 of IPC passed in 1996, it is advised that state criminal policy makers criminalize formation, management, or membership in organized groups created to commit smuggling crime in order to prevent crime to be occured and appropriate punishments should be set for such cases.

\section{References}

Aidin, M. (2012). Smuggling acts and sanctions, adalet, publications, Ankara.

Albayrak, M. (2012). Criminal code of Turkey. Adalet Publications. Ankara.

Asadi, S. H. (2007). Transnational organized crimes. Mizan publications, Tehran.

Bahrami, M., \& Ghasemi, B. (2007). Smuggling pathology in Iran. Farabi Institute Publications, Tehran.

Bakhshinejad, M. (2001). Criminological survey of smuggling goods in Sistan and Baluchestan State, M.A. thesis criminal law and criminology, Tehran Central Branch, Islamic Azad University.

Borricand. J. F. (1999). Organized crime and criminal law, translated by A. H. Najafi Abrandabadi. Legal research journal of Shahid Beheshti University, (4).

Ertuğrul, M. (2004). Code of against smuggling goods. Seçkin Publications, Ankara.

Günay, E. (2007). Code of against smuggling goods and relative subjects. Seçkin Publications, Ankara.

Günay, E. (2009). Evaluation of custom smuggling goods cases. Seçkin Publications, Ankara.

Javanmard, B. (2013). Differential criminal procedure in transnational organized crime. Tehran, Javedaneh Publications.

Sadeghi, H. (1997). International criminal law. Mizan Publications, Tehran.

Seif, A. (1999). Smuggling goods in Iran. Islamic parliament of research center.

Tavasolizadeh, T. (2013). Prevention of economic crimes. Jangal Publications, Tehran.

\section{Copyrights}

Copyright for this article is retained by the author(s), with first publication rights granted to the journal.

This is an open-access article distributed under the terms and conditions of the Creative Commons Attribution license (http://creativecommons.org/licenses/by/4.0/). 